\title{
Critiquing Critique
}

\author{
Delfo C Canceran*
}

\begin{abstract}
This paper attempts to briefly sketch the discursive development of critique in critical theories from modernity (Kant and Marx) to postmodernity (Foucault and Butler). Critique has evolved from negative criticism of the product or output of discourse to the production of or the possibility of discourse. Moreover, there has been a movement from a framework of critique to the critique of alterity (Levinas). The paper demonstrates that this Levinasian critique has shifted from the auto-critique (focus on the self) to alter-critique (focus on the other). The other not just returns the gaze of the self but also contests that gaze in the name of justice.
\end{abstract}

Keywords: Critical Theory, Enlightenment and Modernity

\section{Introduction}

Critique is a modern construction of the enlightenment. ${ }^{i}$ During the Enlightenment, philosophers relied on the faculty of reason as the primary source of authority and legitimacy. Enlightenment enabled people to use their reason in the pursuit of knowledge, direct their action in the public sphere and achieve their goal towards emancipation and autonomy. As a precondition, it was argued that reason should be unfettered from the clutches of tradition and authority. In that way, it can freely exercise its faculty in advancing individual liberty and religious tolerance. The government and the church were the main targets of the critique of enlightenment as it was argued that the former stifled and retarded maturity or

* University of Santo Thomas, Philippines; delfocanceran@yahoo.com 
advancement of reason and defended tradition and authority. By insulating themselves from critique, the government and church effectively delegitimised themselves from the public. To have legitimacy, the government and church must have passed the test of critique. Enlightenment negated the despotism of the absolute monarchy of the government and rigid dogma of the ecclesiastical authority of the church. In particular, the institutional church was being criticised because of its defence of hierarchy and dogma. The hierarchy guarded the dogma against any contagion and sacrilege. Enlightenment in a way was a critique of medieval philosophy that put more focus on tradition and authority.ii The light of reason in the enlightenment was contrasted with the dark ages of medievalism. Reason, they argued, can cast out the prevailing darkness and reveal the illuminated reality. To be enlightened, people must use their reason and emancipate themselves from ignorance.

\section{Critique of Immanuel Kant and Karl Marx}

In the period of modernity, the argument from critique was associated with Immanuel Kant who focussed on the understanding of critique in his philosophical reflections. In fact, Kant formulated the dictum that "everything must submit to critique, even reason itself" (Ground, 2012, p. 7; Raffnsøe, 2015, p. $1)$. In this sense, nothing was spared from the omnipotence of critique.iii Both the outside world of things and the internal world of knowledge were subject to critique (Kant, 1996; Foucault, 1984, pp. 32-50). For Kant, the mind possessed structures that filtered the chaos in the world and made sense of that world. The transcendental ego or self synthesised the world by positing a priori categories which constituted human consciousness and organised human perceptions (Olsses, 2003, p. 81). Reason gave unity and order to cognitions and experiences (McQuillan, 2012, p. 75). Kant overturned metaphysics by proclaiming the death of metaphysics and installed epistemology by elevating the place of reason. ${ }^{\text {iv }}$ The onto-theology of God was replaced by the epistemology of man that questioned tradition and authority and aimed for liberty and autonomy. It was no longer the omniscience of God, but the rationality of man that occupied the centre stage. 
Moreover, Kant split the disciplinary domains of politics and philosophy. Politics referred to the domain of the state that sanctioned governmental actions and protected the common goods. Philosophy was the domain of reason that arbitrated governmental actions and public goods. Philosophy could only exercise its function if reason remained unconstrained from government intervention and repression. Rationality, unfettered from tradition and authority, defined the essential nature of man and reason became the court that arbitrated contestations. In Kant, critique operated not only in philosophy but also questioned the legitimate grounds of various public and governmental agencies.

Aside from Kant, Karl Marx was another heir of the enlightenment. Marx employed the immanent critique by scrutinising the internal contradictions in society (Marx \& Engels, 1978, pp. 331-362). In this sense, the critique was analytical as it clarified the reality of human nature and practical as it pursued the struggle of the workers. (Calikates, 2012, pp. 101-102). Capitalism split society into two classes - the bourgeois class and the proletariat class. The private property of the bourgeoisie enslaved the proletarians in this class division because they were tied up at the mercy of the capitalists. The capitalists monopolised the profit and the workers received the less than minimum wages because the bourgeois class who owned the capital exploited and oppressed the proletariat from their labour. Marx criticised bourgeois society because it fostered dependency analogous to a master and slave relationship. For Marx, the bourgeois class employed ideology to advance its selfserving interests and at the expense of the proletariat class. Ideology was a false consciousness that obscured reality and masked misery. The ruling class controlled the reigning ideas. They did not only control material wealth but also intellectual ideas. This society maintained the power of the capitalists that exploited and oppressed labour. In effect, labour was alienated from its nature because its creative power was taken away from it and snatched by the capitalists. Both capitalism and religion were instruments of the bourgeois against the toiling labour. Capitalism and religion alienated people from their natural capacity. Human nature was a self-creation through its labour and production. Moreover, religion was likened to the opium of the people that only hid or romanticised sufferings. The workers suffered from exploitation 
and oppression by the capitalists who extracted surplus value from labour. Religion provided relief and consolation from that desolation and affliction. Thus, religion was "a symptom of real social and political conflicts rather than a mere delusion or error" (Calikates, 2012, p. 110). Instead of liberating them from this slavery, religion taught them to be patient and optimistic to the afterlife (Marx, 1978, p. 15). Both capitalism and religion needed to be subjected to a defetishising critique (Calikates, 2012, p. 105). This critique aimed at freeing the consciousness of the workers and empowering them to engage in a collective struggle and freedom. This dependency and slavery would only end once capitalism and religion were eliminated from society.

The heritage of Kantian idealism and Marxist materialism has influenced the formation of critical theory. Critical theory is based on the reflexive turn in philosophy which "offers a distinctive answer to the problem of rationality [...] and inquiry into the nature and scope of human knowledge. [..]" (Peters, Olssen \& Lankshear, 2003, p. 17). Critique is basically applied to knowledge and the activities promoted, created and validated by and in the society. Knowledge is a cognitive construction by the transcendental ego or the ruling class. The transcendental self synthesises the data from the world and categorises them into intelligible scheme. It can oversee the competing claims and judge convincing claims. The ruling class produces the ideas and controls the mentality of the workers. It propagates an ideology that deceives the workers and perpetuates their alienation from their nature. However, this knowledge can be questioned and undone by the tribunal of reason and struggle for emancipation. This ideological claim can be unmasked through critique and the alienation can be undone. Enlightenment can emancipate the people from ignorance and from manipulation. Thus, critical theory influenced by Kant and Marx can emancipate or liberate both knowledge and society from remaining immature and oppressed by the power-that-be that distorts the worldview and that alienates people from their nature. Since it is constructed by the human mind and the ruling class, knowledge can be freed from immaturity and manipulation. When people recognise the construction and manipulation of knowledge, they can emancipate themselves from ignorance and alienation. 


\section{Critique of Michel Foucault and Judith Butler}

Michel Foucault takes the clue from the enlightenment and Kantianism in his brand of critique.v For Foucault, critique is not just a matter of fault-finding or nay-saying by showing the errors and fallacies of reason (Foucault, 1997). Critique should go deeper into structures of reason or knowledge. Foucault questions the assumptions or presuppositions that frame the mind. Thus, the Kantian transcendental ego or self is interrogated from its mental categories that construct its knowledge. The framework authorises the deployment of those discourses or theories. Foucault asks a set of questions like "in what way and by what right" that enable the deployment of such discourses and theories (Butler, 2009, p. 778). Thus, the critique goes to the core of the matter, that is, the framework of mind or mindset of thought that permits or prohibits the deployment of such discourses or practices. When reason exposes that self-legitimation, it inevitably enters into a question of power. Foucault argued that knowledge and power are inseparably linked. The self is subjected and subjectivated by this matrix of power and knowledge (Foucault, 1982; Foucault, 1980). Foucault asks the question: "What is the relation of knowledge to power such that our epistemological certainties turn out to support a way of structuring the world that forecloses alternative possibilities of ordering?" (Butler, 2001).

However, Foucault departs from Kant's splitting of politics as a domain of the state or government and philosophy as the domain of unrestrained reason. When Kant made this separation, he subjected or subsumed politics to philosophy. Philosophy is instituted as unconstrained or unrestrained by any intervention or subordination so that it can freely exercise its power. Philosophy is installed as an extraordinary arbiter of the discipline of politics. This freedom defines the task of philosophy. Freedom is a precondition for its critical function in politics. The withdrawal of state intervention provides philosophy with a privilege and leverage in the exercise of reason in critique (Butler, 2009, p. 779). However, in the production of knowledge, politics and philosophy are implicated or intertwined in its exercise or practice. Thus, the questions of "in what way" and "by what right?" expose the legitimating ground of justification of reason and the legitimating 
power of the self in discourse (Butler, 2009, p. 778). The splitting of politics and philosophy advantages philosophy and subjects politics into its arbitration. In this split, philosophy seems to be insulated from politics and such insulation places philosophy to a privilege status as the arbiter or court of uncontaminated truth. In Foucault, this disciplinary division between politics and philosophyshould be transgressed and negotiated.

In Foucault's view, critique functions in two different domains. First, critique begins with the regime of rationality in questioning the demand for absolute obedience and second, critique inquires on the governmental obligation imposed on subjects to a rational and reflective evaluation (Butler, 2009, pp. 787-788). Thus, Foucault proposes an attitude of critique which he identifies as an ethos, that is, as a way of acting or behaving in the transformation of the self. One should not subordinate himself or herself to the regime of authority but one must elaborate or produce himself or herself into a project of self-invention. The first function is negative because it is a refusal to submit oneself to authority, but the second function is positive since it elaborates aesthetics of the self. In this sense, the refusal is a condition that opens space for this self-creation (Butler, 2009 , p. 787). Butler argued that "this capacity to form reasons will be importantly linked to the self-transformative relation [...]. To be critical of an authority that poses as absolute requires a critical practice that has self-transformation at its core" (Butler, 2001).

Following Foucault, Judith Butler proffers her version of critique. However, her critique is elevated into a meta-critique since it is on the level of a critique of critique. She explains that this critique of critique is an elaboration and interrogation that "call into question the implicit and uncritical preconditions of its operation" (Butler, 2009 , p. 781). If we allow critique to have criteria and agenda as a precondition, then it is already a priori, restricted or constrained in its exercise because one is forced to enter and accept such requirement that allows and prohibits critique. This restriction or constraint constitutes a delimiting power in the exercise of critique. In that case, "we need something like a critique of critique to understand these other differentiating effects of power and to undo their effects" (Butler, 2009, p. 783). These effects are manifested in the production of knowledge that delimit and determine their 
possibilities. Thus, "critique is the operation that seeks to understand how delimited conditions form the basis for the legitimate use of reason in order to determine what can be known, what must be done, and what may be hoped" as the aims of critique (Butler, 2009, p. 787). Thus, the aim of the critique is to look into the effects of power and the delimited conditions of rationality that restrains or constrains the free exercise of reason.

\section{Foucault and Emmanuel Levinas}

According to Butler, Foucault provides a critique of the subordination of the self to the regime of authority. This critique focuses on the ethos of the self as a matter of self-invention or selftransformation. Butler ignores another critique that Foucault broaches in her discussion on the linkage or connection between power and knowledge. Foucault mentions the critique of the insurrection of subjugated knowledge. He highlights the power that includes and excludes, allows and prohibits in the production of knowledge in institutions. The reemergence of this knowledge can interrogate the established knowledge where criticism can perform its task (Olsses, 2003, p. 89). He deals with the politics of knowledge as resistance to power. If there is power, there is resistance, as he once asserted. The subjugated knowledge is buried on the ground and pressed on the margin. They are reduced to invisibility or relegated to unknowability. Foucault wanted to reclaim subjugated knowledge to counter or interrogate the hegemonic knowledge operating in our society. Knowledge comes from the subaltern groups that struggle for expression and representation. Subjugated knowledge has been undermined and discredited in discourses and theories. As such, they must be articulated and represented in discourses.

One can link subjugated knowledge to the Levinasian Other. However, we need a caveat that this knowledge is not enclosed or finalised but always tentative and provisional so that one does not fall into the trap of totalisation or totalitarianism. Totalisation or totalitarianism forecloses the possibility of alterity or alteration. It relies on its self-sufficiency and self-assurance that it can autocorrect itself due to its reflexivity or reflectivity. In this sense, consciousness originates from the self or ego and develops this 
consciousness from its own faculty. In this perspective, knowledge is organised and systematic. In a way, this knowledge has been sedimented into tradition and therefore it resists alteration or transformation. This knowledge is merely reproduced or passed on to others who will just mimic or repeat it. If ever it changes, knowledge merely accommodates or assimilates alterity; it does not respect it. Alterity is merely eaten up or swallowed up within the self that expands in the process of absorbing or taking the Other. The Other is internalised and digested into the self. In this sense, the Other is actually not just marginalised but excluded by the self because there is no space left for the Other by the self that totally obliterates it.

Emmanuel Levinas inverts the hierarchy of the self and the other and asserts the priority of the other to the self (Moyn, 2005). The Other is the one other than me (Egea-Kuehne, 2003, p. 111). Historically, the Other has been marginalised and excluded from the dominant western discourses or philosophies. Levinas provides the space for the Other by inverting the self/other hierarchy and by prioritising the Other. The Other critiques the dominant self and offers an alternative world. We have to note that we can expand the scope of the Other to include the subordinated women, discriminated colonies, slaved races, relegated men and disadvantaged poor, to name a few. Thus, the Other is no longer homogenous but heterogeneous because it can refer to many others marginalized or exclude by the dominant self. These Others interrupt the self that arrogates the power of ventriloquism and totalitarianism. Levinas asks the questions: "What does it mean to be on the margins of the knowable and the known?" and "How does thinking, being, creating and acting as and from the position of the Other transform the meaning of the thought and imaginary of each?" (Drabinsky, 2011, p. xiii).

As a philosopher of ethics, Levinas develops the philosophy of the (face of the) Other. For Levinas, the Other signifies infinity. Drabinski asserts that "the Other exceeds all categories" (Drabinski, 2011, p. 2), that is "outside language, outside conceptualization, outside notion of teleology" (Drabinski, 2011, p. xii) that neutralises or abrogates difference. Thus, the Other is radical because it is immeasurable or incalculable. Drabinski articulates that "radical 
difference signifies a relation of obligation, a sense of responsibility that exceeds my grasp and my comprehension yet at the same time weighs upon me and makes me the subject I am" (Drabinski, 2011, p. xii). The self cannot grasp or capture the Other because it eludes or escapes any grasp and comprehension. Levinas relies on the biblical message of the Other that lays the foundation on his ethics of the Other. The I is in a face-to-face encounter with the Other. In that encounter, the I encounters directly the face of the Other human being and indirectly the transcendental Other - God. EgeaKuehne observed that "in the face-to-face encounter, he/[she] sees, beyond all knowledge, an elevation of the ethical order, an indirect encounter with a transcendental God, a relation to Infinity" (EgeaKuehne, 2003, p. 110). Ethics is defined as a relation to the Other. In that encounter, the Other appeals to us. We cannot escape it. The Other calls us to responsibility and we must heed it with humility. Thomas stated that "responsibility is not simply bad conscience nor conscience as the fact that one hears the silent call of being. Responsibility is prior to the response given to the call" (Thomas, 2004, p. 132).

The face is an invitation to justice. It opens up the possibility of response, dialogue or exchanges out of which reason and knowledge are produced (Thomas, 2004, p. 106). Thomas notes, "Levinas insists that the face to face relation is the ethos of reason itself. It does not found reason but opens reason to critique and renewal" (Thomas, 2004, p. 108). The Other awakens me to the question of justice but, at the same time, confronts me with the question of responsibility (Thomas, 2004, p. 111), "in other words, justice is conceived of as arising as a response to the suffering of the Other" (Thomas, 2004, p. 116). Justice is the acknowledgement of and respect to the Other (Egea-Kuehne, 2003, p. 115). Levinas is concerned with the ethical justice which "arises out of a singular relation to another and does not presuppose a pre-existing universal" (Thomas, 2004, p. 117). The Other assumes a concrete particularity and becomes a model of social relation. ${ }^{\mathrm{vi}}$ In this sense, "to be in relation to the Other is to [...] offer a critique of justice conceived in traditional moral or juridical terms" (Thomas, 2004, p. 119). The traditional or juridical justice is measured or calculated in terms of the due or right of the Other. In this sense, the Other is no longer infinite but finite. The self measures or calculates the due or 
right given or accorded to the Other. The self occupies the superior status in relation to the inferior Other. Moreover, Levinas reverses the hierarchy of freedom and justice. For him, justice precedes freedom. Thomas further notes, "For Levinas, the question of freedom is concerned solely with securing a place for the same (self) - securing the identity of subjectivity within itself and affirming a right to be on the grounds of a certain necessity or truth. The question of justice for Levinas is not one of how to guarantee this right but putting of it into question. The Other calls the subject into question, thereby putting the obligation with regard to the Other before obligation to oneself" (Thomas, 2004, p. 122). In short, justice is a responsibility to the Other that calls into question the freedom and identity of the self. The freedom and identity of the self are subordinate to the priority and summon of the Other that provides its freedom and identity.

\section{Conclusion}

Critique dominantly remains on the level of fault-finding or naysaying that shows the flaws and fallacies of certain philosophers or philosophies. Scholars have not transcended that notion perhaps because that can easily be detected from their works or demonstrated by logic. To show that scholars have transcended these philosophers or philosophies, they title their works in a way that overcomes these flaws and fallacies using the word 'beyond' such as 'beyond dialectics' and 'beyond being'. There is a presumption that reason is equipped with the capacity to unveil error and lack and eventually rectify or fill them. Thus, reason can disclose the fault of reason and overcome it. In a way, reason can err but it can be corrected by a better reason and thereby correct it once it realises that the alternative is more cogent. There is a tendency of some scholars to follow the unveiling or discovering of mistake or dearth on their arguments and thereby overcoming or transcending them. These scholars have criticised these defective or erroneous arguments and offered their corrected or expanded version. They still work within general logic and discourse of those philosophies and philosophers but only surmounted their setback or impasse. In this sense, critique does not only offer better but also higher alternative explanation or interpretation of the problem. 
Moreover, the notion of critique is also associated with the inquiry that investigates or examines the works or arguments forwarded by scholars. Inquiry finds out the answer to a mystery. However, the inquiry is limited in its operation because it depends on the availability or accessibility of the materials given for examination or investigation. In this way, the inquiry is circumscribed or bounded by the limits imposed on its operation. Thus, the inquiry is not only limited but also enclosed within that particular maneuver. Critique goes to a deeper operation because it "takes place through the formulation of a set of questions" (Butler, 2009, p. 776). If inquiry answers a question, critique asks a question. Questions are more important than answers in the critique. One has to interrogate the limits imposed and the conditions required in the operation of reason. These limits and conditions can prohibit that function of critique and therefore eventually paralyse it. In order to interrogate these limits and conditions, we need to turn ourselves not to inward movement of self-reflection or self-critique but to the primordial presence or summon of the Other. If we stick to the self as self-creation or self-transformation, we may end up with the Cartesian solipsism or with Freudian narcissism because it tends to be self-referential or self-enclosed. However, if we turn to the Other and not to the self, we encounter the Other as a revelation and critique of the self. There is the Other calling me and appealing to me. I cannot ignore or evade the Other. The critique, therefore, shifts from mere aesthetics to ethics. The I is related to the Other, not by mere epistemology but by responsibility. This responsibility is boundless and limitless because the Other is infinite.

Critiquing critique relies on what Foucault calls 'permanent critique' because one should never be complacent but always be wary of the possibility of marginalisation and exclusion of other reasons and rationalities. Critique is a constant and restless in suspecting closure and opening spaces for alterity. Critique is possible because there is an alternative way of thinking and doing otherwise for the sake of the many Others. Discourses and practices can be undone because they are not born, but made. Others - the subaltern groups - have been marginalised or excluded historically and epistemologically in the representation of their knowledge. If ever they are represented, the self represents them and, if ever the self represents them, it under-represents or misrepresents them. In 
either case, they are at the mercy of the self. In this way, the self remains superior and powerful in representing its Others. We need to reverse the hierarchy and demote the self. Others should be given the priority and space in expressing themselves, their experiences and their identities. They can return the gaze of the self that encloses or limits them and they can confidently represent and assert themselves. They should be allowed to express themselves in their own voices and words. The self in turn should listen and commiserate with the Others. In this way, we democratise the space for the advent and alterity of the Others that surprises and transforms the self. The self is then responsible for the Other.

\section{References}

Asad, T., Brown, W., Butler, J., \& Mahmood, S. (2013). Is critique secular?: blasphemy, injury, and free speech. Oxford University Press.

Judith, B. (2009). Critique, dissent, disciplinarity. Critical Inquiry, 35(4), 773-795.

Judith, B. (2001). What is Critique?: An Essay on Foucault's Virtue. http://eipcp.net/transversal/0806/butler/en. Accessed February 10, 2018.

Robin, C. (2012). Karl Marx: critique as emancipatory practice. In K. de Boer and R. Sonderegger (Eds.), Conceptions of critique in modern and contemporary philosophy. New York: Palgrave Macmillan.

Bregham, D. (2017). Critique as critical history. London and New York: Palgrave Macmillan.

Drabinski, J. E. (2011). Levinas and the postcolonial: race, nation, other. Edinburg: Edinburg University Press.

Egea-Kuehne, D. (2003). Levinas's Ethicopolitical order of human proximity: 'The Quest for Justice.' In M. Peters, M. Olssen and C. Lankshear (Eds.), Futures of critical theory: dreams of difference. Lanham: Rowman \& Littlefield Publishers, Inc.

Foucault, M. (1982). The subject and power. In H. L. Dreyfus and P. Rabinow (Eds.), Michel Foucault: beyond structuralism and hermeneutics. Chicago: University of Chicago Press.

Foucault, M. (1997). What is critique? In S. Lotringer and L. Hochroth (Eds.), The politics of truth. New York: Semiotext(e).

Foucault, M. (1984). What is Enlightenment? In P. Rabinow (ed.), The Foucault reader. New York, Pantheon Books.

Foucault, M. (1980). Power/knowledge: Selected interviews and other writings, 1972-1977. New York: Pantheon. 
Ground, W. (2009). Introduction. In T. Asad, W. Brown, J. Butler, and S. Mahmood. Is critique secular?: blasphemy, injury, and free speech. Los Angeles, Berkley and London: University of California Press.

Hendricks, C. (2008). Foucault's Kantian critique: philosophy and the present. Philosophy \& Social Criticism, 34(4), 357-382.

Kant, I. (1996). An answer to the question: what is enlightenment? Trans. James Schmidt. Los Angeles: University of California Press.

Kant, I. (1929). Critique of pure reason. Trans. Norman Kemp Smith. New York: MacMillan.

Levinas, E. (1969). Totality and infinity: an essay on exteriority. Trans. Alphonso Lingis Hague: Duquesne University Press.

Levinas, E. (1991). Otherwise than being or beyond essence. Dordrecht: Kluwer Academic.

Marx, K \& Engels, F. (1978). Manifesto of the Communist Party. In R. Tucker (Ed.), The Marx-Engels Reader. New York: W. W. Norton.

Marx, K. (1978). Contribution to the critique of Hegel's philosophy of right. In R. Tucker (Ed.), The Marx-Engels Reader. New York: W. W. Norton.

Colin, M. (2012). Beyond the limits of reason: Kant, Critique and enlightenment. In K. Boer and R. Sonderegger (Eds.), Conceptions of critique in modern and contemporary philosophy. New York: Palgrave Macmillan.

Moyn, S. (2005). Origins of the Other: Emmanuel Levinas between revelation and ethics. Ithaca and London: Cornell University Press.

Olssen, M. (2003). Foucault and critique: Kant, humanism and the human sciences. In M. A. Peters, M. Olssen, \& C. Lankshear, C. (Eds.). Futures of critical theory: Dreams of difference, 73-102.

Peters, M. A., Olssen, M., \& Lankshear, C. (Eds.). (2003). Futures of critical theory: Dreams of difference. Rowman \& Littlefield.

Raffnsøe, S. (2015). What is Critique?: The Critical State of Critique in the Age of Criticism. Copenhagen: Department of Management, Politics and Philosophy.

Louise, T. E. (2004). Emmanuel Levinas: ethics, justice and human beyond being. New York and London: Routledge.

i Greek Philosophy has its krisis. For Wendy Ground, "krisis integrates polis rupture, tribunal, knowledge, judgment and repair, at the same time that it links subject and object in practice. Krisis refers to a specific work of the polis on itself - a practice of sifting, sorting, judging, and repairing what has been rent by a citizen violation of polis law or order" (Ground, 2009, p. 9).

ii There is an interested debate on the relationship between critique and secularism. Critique and secularism arose in the modern period and 
scholars assume that critique is a secular rationality (Asad, Brown,Butler and Mahmood, 2009).

iii According to Foucault, Kant founded two critical traditions in philosophy. First, he founded that critical tradition that asks the question: Under what conditions that true knowledge is possible? Second, he founded that critical tradition that asks the question: "What is the contemporary field of possible experience?" (Olssen, 2003, p. 74).

iv McQuillan is more careful in the full death of metaphysics in Kant by distinguishing the special metaphysics and general metaphysics. For McQuillan, "Kant excludes empirical considerations and the traditional concerns of metaphysica specialis from [general] metaphysics precisely because he is committed to the view that metaphysics is a system of pure speculative reason. (McQuillan, 2012, p. 76).

$v$ There are interesting discussions on the Kantianism of Foucault. Scholars argue on the implication of Kantianism in the whole philosophy of Foucault on power and subject (Hendricks, 2008).

vi Levinas speaks of The Third which refers to many others in society. Although he speaks frequently of the Other, Levinas does not discount the place of many others living in society. Nonetheless, the face -to-face encounter with the Other is the exemplary model of any social relationship. (Thomas, 2004, p. 109-113. 